\title{
REKONTEKSTUALISASI PEMAKNAAN JIHÂD DALAM PERSPEKTIF HUKUM ISLÂM
}

\author{
Taufiqurrahman \\ (Dosen Tetap pada Jurusan Syari'ah STAIN Pamekasan dan alumni S2 dan \\ S3 Universitas Negeri Malang)
}

\begin{abstract}
Abstrak:
Resonansi istilah maupun seruan jihâd sungguh terasa lebih "menggetarkan" nurani kaum Muslim, terlebih bagi pemeluk agama lain, daripada penggunaan kosakata lainnya yang bermakna serupa. Apalagi, jika istilah atau seruan itu diiringi dengan pekik-suara Allâhu Akbar!!! tiga kali, seolah-olah genderang perang-suci agama baru saja ditabuh dan pasukan mulai dikomando menuju the killing field. Tidak jarang, teriakan keras Allâhu Akbar pun diserupakan dengan kesiapan ber-jihâd, dalam arti berperang secara fisik melawan orang-orang yang "mempertontonkan" perilaku munkar, batil, kâfir, dan dhalim dalam segala bentuk, level, maupun konteksnya sesuai dengan klaim-persepsif kebenaran sepihak pada golongan tertentu. Dalam realitasnya, para pelaku aksi-aksi kekerasan seringkali menggunakan istilah jihâd sebagai dasar-pembenar atas tindakan yang beraneka motif. Persoalannya, apakah jihâd itu "berwajah" tunggal? Berlaku untuk semua konteks? Identik dengan kekerasan atau peperangan? Atau masih adakah ruang tersisa untuk memaknakannya kembali menurut ragam konteksnya sebagai perspektif baru yang mencerahkan dan membebaskan umat dari belenggu yang bernuansa kengerian?
\end{abstract}

Kata kunci:

jihâd, mujâhadah, perang, kontekstualisasi.

\section{Pendahuluan}

Dalam kamus bahasa Arab, istilah jihâd terambil dari akar kata kerja jâhada-yujâhidu-jihâdan (جاهد يجاهد جهادا) yang secara etimologis berarti usaha yang sungguh-sungguh جاهد فى الأمر أى ) 
جد), upaya sepenuh hati (إجتها وتجاهد فى الأمر), usaha serius dengan sepenuh tenaga (بذل جهده), dan melakukan secara all-out ( مجهود أى ) مرنى (أجها على الفعل Istilah serupa dalam rumpun kata yang sama adalah ijtihâd dan mujâhadah yang masing-masing memiliki arti: bersungguhsungguh untuk menemukan kebenaran dan bersungguh-sungguh dalam menghayati kebenaran. Sedangkan istilah jihâd itu sendiri secara spesifik bermakna bersungguh-sungguh untuk menegakkan kebenaran. Dalam konteks keberagamaan, ketiga istilah (baca: konstruks) itu diposisikan saling melengkapi (complementary) sebagai "pembentuk" proses pemahaman konseptual istilah jihâd (berjuang) yang dinisbatkan kepada para pelakunya, mujâhid (pejuang).

Posisi dan penggunaan istilah jihâd dipandang sangat istimewa karena merupakan aktualisasi atau perwujudan-konkret dari praksis keberagamaan individu Muslim. Bahkan, amalan jihâd menjadi parameter dan bukti keberagamaan pribadi Muslim atas keseriusan iman seseorang dalam bentuk keteguhan persepsi, pikiran, pendapat, pandangan, sikap, dan penghayatan dalam nurani yang harus ditegakkan (baca: diperjuangkan!) dalam pergaulan hidup sehari-hari. Oleh karenanya, jihâd diposisikan pada derajat yang tinggi sebab ada keharusan mewujudkannya pada kehidupan nyata sebagai evidensi keberagamaan individual Muslim.

Posisi jihâd itu tampaknya demikian istimewa sebagaimana penegasan Allâh swt. yang termaktub di dalam al-Qur'ân Surat Âli 'Imran (3) ayat 142 berikut ini.

$$
\text { أم حسبتم أن تدخلوا الجنة ولما يعلم الله الذين جاهدوا منكم ويعلم الصابرين }
$$

Apakah kalian mengira akan masuk Sorga padahal belum tampaknyata bagi Allah orang-orang yang berjihad di antara kalian dan belum tampak-nyata (pula kalian sebagai) orang-orang yang sabar?)2

\footnotetext{
${ }^{1}$ Ahmad Warson Munawwir, Al-Munawwir: Kamus Arab-Indonesia (Yogyakarta: Pondok Pesantren Al-Munawwir Krapyak, 1984), hlm. 234; Adib Bisri \& Munawwir AF, Al-Bisri: Kamus Arab-Indonesia dan Indonesia-Arab (Surabaya: Pustaka Progresif, 1999), hlm. 88.

2 Departemen Agama RI, Al-Qu'rân dan Terjemahnya (Jakarta: Proyek Pengadaan Kitab Suci Al-Qur'ân, 1999), hlm. 99. Dalam rujukan ini, terdapat tambahan keterangan bahwa jihâd antara lain dimaknakan: (a) berperang untuk menegakkan Islâm dan
} 
Dalam firman Allâh itu dinyatakan secara tegas bahwa jihâd menjadi parameter dan bukti sejati keberimanan individu Muslim dalam derajat yang amat tinggi dan nilai yang amat berharga. Pada surat al-Tawbah (9): 24, maksud ayat itu dielaborasi lebih lanjut yang berisi komitmen sejati keberimanan kelompok individu Muslim kepada Allâh swt. melalui jihâd di jalan-Nya (jihâd fî̀ sabîlillâh), yaitu:

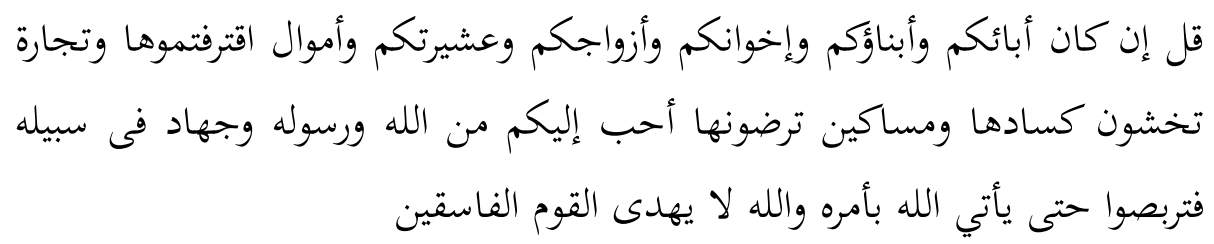

Katakanlah (kepada umatmu, wahai Muhammad)!: "Jika bapak-bapak kalian, anak-anak kalian, saudara-saudara kalian, istri-istri kalian, keluarga kalian, harta kekayaan yang kalian tumpuk, harta perniagaan yang kalian pertahankan, dan rumah-tinggal yang kalian senangi adalah lebih kalian cintai dibandingkan Allâh, Rasûl, dan jihâd di jalan-Nya maka tunggulah (suatu ketetapan) yang bakal diputuskan Allâh bagi kalian!" Allâh tidak memberi petunjuk bagi golongan orang-orang fasik). ${ }^{3}$

Kesejatian iman sebagai alat bukti dan parameter atas kesungguhan jihâd bagi individu mukmin dapat diwujudkan pula melalui pengorbanan harta maupun jiwa sebagai realisasi "keberpihakan" kepada ketaatan dalam pelaksanaan ajaran Allâh swt. Keberpihakan yang diungkapkan Allâh dengan nada penegasantawaran dikomunikasikan oleh-Nya sebagaimana tertera di dalam alQur'ân surat al-Shâf (61): 10-11 berikut ini:

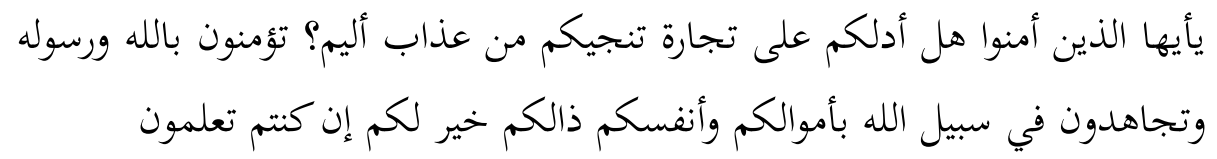

melindungi orang-orang Islâm, (b) memerangi hawa nafsu, (c) mendermakan harta benda untuk kebaikan Islâm dan umat Islâm, dan (d) memberantas yang bathil dan menegakkan yang haqq.

${ }^{3}$ Departemen Agama RI, Al-Qurân, hlm. 281. 
Wahai orang-orang yang beriman! Maukah kalian Aku tunjukkan bisnis (urusan, perniagaan) yang dapat menjadi perlindungan bagi kalian dari siksa yang pedih?; (yaitu:) berimanlah kepada Allâh, kepada Rasûl-Nya, dan berjihâd di dalam jalan Allâh dengan harta maupun jiwa kalian! Itulah yang lebih baik bagi kalian jika kalian mengetahuinya. ${ }^{4}$

Berdasarkan penegasan dari tiga kutipan ayat pada firman Allâh tersebut, tampaknya jihâd harus dimaknakan kembali menurut konteks kepatuhan hamba kepada Sang Pencipta untuk meneguhkan sikap mental-kognitif yang berpihak kepada ajaran-Nya dan memantapkan perilaku dalam realitas kehidupan dengan cara menghadirkan kebenaran. Oleh karena itu, jihâd harus diposisikan sebagai bagian dari bentuk-bentuk perjuangan yang penuh dengan spirit pengorbanan untuk memunculkan dan membela kebenaran dalam berbagai aspek dan realitas kehidupan.

Itulah yang dikenal dengan makna rekontekstualisasi pemaknaan jihâd sebagai reformulasi tawaran makna baru. Jika tawaran demikian dapat disepakati, pengungkapan istilah atau seruan jihâd tidak lagi menggetarkan dan menakutkan diri, apalagi pihak lain, karena perintah untuk ber-jihâd sesungguhnya bermakna menghadirkan dan membela kebenaran. Sebaliknya, aktualisasi jihâd, sebagai implementasi keimanan sejati, justru harus disambut dengan penuh suka cita, terutama bagi sebagian besar warga-bangsa yang terus merindukan kehadiran dan pembelaan kebenaran serta mendambakan keadilan sebagai awal perwujudan keberaturan dalam tatanan sosio-yuridis yang merata dan berlaku bagi semua orang tanpa kecuali.

\section{Jihâd: Momok-Menakutkan}

Dalam realitas kehidupan, penyebutan istilah maupun perwujudan praksis jihâd dewasa ini menjadi momok yang menghawatirkan bagi pemeluk Islâm, lebih-lebih menjadi menakutkan bagi pihak-pihak eksternal. Kondisi itu tercipta karena telah terjadi pergeseran pemahaman dari makna dan konteks asalnya. Dalam implementasinya, jihâd dipahami oleh sebagian komunitas Muslim identik dengan tindak kekerasan untuk menyelesaikan masalah, yaitu berperang (berjuang dalam arti spesifik!) melawan

\footnotetext{
${ }^{4}$ Ibid., hlm. 929.
} 
kelompok atau anggota kelompok tertentu yang secara dogmatisdoktrinal harus "dimusnahkan" berdasarkan perspektif penafsiran parsial-eksklusif maupun sepihak atas hukum-agama dengan tanpa menyisakan ruang dialogis yang setara. Apalagi, ada sebagian golongan yang cenderung memaknakan jihâd dalam wajah-tunggal yang tidak menerima arti lain kecuali tindakan kekerasan fisik yang ditujukan kepada orang atau sekelompok orang yang tidak sealiran (semadzhab) dan diklaim sebagai musuh yang juga bersifat fisik. Landasan hukum agama yang biasa dijadikan rujukan-hukum mereka adalah firman Allâh Swt. sebagaimana tertera di dalam AlQur'ân surat al-Tahrîm (66): 9, yaitu:

$$
\text { يأيها النبي جاهد الكفار والمنافقين واغلظ عليهم ومأواهم جهنم وبئس المصير }
$$

Wahai Nabi! Jihâdilah orang-orang kâfir dan orang-orang munâfik; dan bersikaplah tegas terhadap mereka! Tempat mereka adalah neraka jahannam dan itu adalah seburuk-buruk tempat kembali).5

Maksud ayat tersebut dapat dipahami bahwa sasaran jihâd lebih ditekankan pada objek personal (yaitu, orang kâfir dan munâfik) dibanding objek impersonal (yaitu, sistem atau tatanan sosio-kultural kekufuran dan kemunafikan). Dalam perspektif demikian, timbul persoalan tafsîr hukum, yakni apakah perintah ber-jihâd pada ayat tersebut harus dimaknakan sebagai perintah untuk melakukan kekerasan fisik terhadap semua orang kâfir dan munâfik, golongan individu yang berbeda pemahaman akidah dengan kaum Muslim? Jika begitu, siapa saja yang digolongkan termasuk orang kâfir dan munâfik itu? Pada kondisi seperti apa berlaku hukum men-jihâd-i mereka? Terakhir, dengan cara bagaimana jihâd itu dilakukan terhadap mereka?

Pada tataran inilah diperlukan upaya untuk membangkitkan daya nalar yuridis, sebagai bagian dari tafsîr hukum agama sehingga pemahaman dan implementasi jihâd tidak berakibat fatal dan konyol yang tidak hanya merugikan pihak lain yang di-jihâd-i melainkan justru berbalik-arah menjadi bumerang yang menimpa diri pelaku jihâd. Pokok pangkal utama dari tindak kekerasan atas-nama agama

\footnotetext{
5 Ibid., hlm. 952.
} 
(jihâd) itu muncul dari eksklusivitas pemaknaan jihâd tanpa ijtihâd dan pemaknaan tunggal bahwa jihâd itu adalah perang, tindakan penyerangan secara fisik.

Pelakunya adalah sekelompok orang yang rata-rata: (a) jauh dari sebutan terpelajar atau terdidik (well-educated) dalam penguasaan ilmu-ilmu agama, (b) sedang membutuhkan pencerahan pemikiran keagamaan dan baru mengenal wacana keagamaan dan keberagamaan, (c) belum teruji kemampuan dan kematangan berpikir ijtihâdiyah-nya, (d) memiliki militansi yang kasar, absurd, dan menyedihkan, serta (e) berniat sungguh-sungguh ingin membela ajaran Islâm tetapi dengan cara yang justru menistakan Islâm karena aksi-aksi kekerasannya itu. Umumnya, mereka bangga karena merasa melakukan tindakan mulia, sebagai pembawa panji-panji jihâd (risâlah islâmiyah) kendati pun mereka melakukannya dengan tindakan brutal penuh kekerasan atas nama agama untuk maksud yang diklaim sebagai penegakan kebenaran (al-amr bi al-makrûf wa al-nahy an almunkar).

Berbagai aksi kekerasan yang dikerangkakan mereka sebagai jihâd seperti serangkaian peristiwa bom bunuh diri di Irak, perang gerilya melawan pasukan multinasional di Afganistan, pembajakan pesawat komersial, peledakan World Trade Center dan Markas Besar Pentagon, perang antargolongan di Ambon dan Poso, tragedi bom Bali I dan II, pengeboman kantor kedubes asing, mal dan hotel di Jakarta, perusakan tempat-tempat ibadah kaum Nasrani di tanah air, serta aksi-aksi kekerasan lain di berbagai lokasi negeri ini merupakan contoh nyata dari perbuatan sekelompok kecil Muslim yang mengklaim diri sebagai pengamal "ajaran suci" jihâd atas nama agama.

\section{Tafsîr Hukum Agama}

Perintah Allâh Swt. kepada Nabî saw. untuk ber-jihâd melawan kaum kuffâr dan munâfiqin dalam al-Qur'ân surat al Tahrîm (66) ayat 9 tersebut perlu diposisikan sesuai dengan konteks pemahaman hukum (agama) Islâm. Persoalan pokok yang layak dipertanyakan-ulang menurut bahasa (baca: tafsîr-hukum) agama adalah siapa sesungguhnya orang-orang yang tergolong kâfir dan munâfik? Secara lughawî, orang kâfir adalah orang yang tertutup (terhalangi) hatinya 
dalam menerima kebenaran Ilâhiyah. Sedangkan secara ishthilâhî, ia berarti orang yang menolak kebenaran ajaran Allâh dan Rasûl-Nya secara lisan, tulisan, atau perbuatan. Istilah munâfik dinisbatkan kepada orang yang mengaku menerima kebenaran ajaran Allâh dan Rasûl-Nya tetapi mengingkari di balik pengakuannya itu.

Apakah kemudian jihâd harus (dan hanya!) diartikan tunggal, yaitu memerangi, menghancurkan, dan memusnahkan (orang kâfir dan munâfik) sebagai sasaran fisiknya? Pemaknaan jihâd sebagai peperangan fisik sesungguhnya tidak dapat diidentikkan begitu saja karena ternyata al-Qur'ân menggunakan istilah spesifik untuk perang, yaitu qitâl. ${ }^{6}$ Jihâd dan qitâl adalah dua istilah yang memiliki pengertian atau makna yang tidak selalu identik. Kendati pun begitu, kedua istilah itu dapat saja dipertukarkan penggunaannya dalam cara dan tujuan yang dibenarkan syara' sesuai dengan konteksnya. Terma yang digunakan al-Qur'ân untuk konteks peperangan adalah qitâl yang secara lughawi berarti membunuh atau saling membunuh dalam dalam ajang (setting dan konteks) peperangan. Sedangkan jihâd digunakan oleh al-Qur'ân untuk terma yang lebih diorientasikan (juga ditekankan) untuk "memerangi" sasaran non fisik (psycholgical and psychosocial enemy) ${ }^{7}$ daripada sasaran secara fisik. Nabî saw. pernah bersabda:

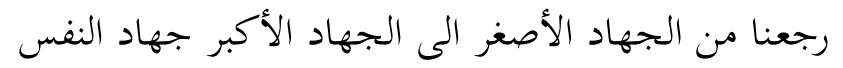

Kita barusaja kembali dari jihâd kecil (yakni peperangan fisik) menuju jihâd akbar (yakni peperangan jiwa), yaitu jihâd an-nafs.

Jihâd an-nafs dipersonifikasikan oleh al-Qur'ân sebagai "peperangan" atas totalitas karakter negatif individu manusia yang cenderung mengotori fitrahnya. Nafs sebagai totalitas manusia itu mencakup nyawa, emosi, pengetahuan, tenaga, pikiran, bahkan

6 Lihat al-Qur'ân, surat al-Anfâl (8): 65); idem, surat al-Hajj (22): 39-40); Idem, alBaqarah (2): 190-193); dan Idem, al-Mumtahanah (60): 8-9.

7 Rasûlullâh saw malah memosisikan jihâd (dalam arti dan konteks perlawanan bersenjata atau peperangan) untuk diorientasikan terhadap jihâd akbar, yaitu perang melawan hawa nafsu yang berdiam pada setiap fisik individu manusia, suatu pertempuran yang tidak berbatas waktu kecuali batas ajal kehidupan. Informasi itu disampaikan Nabî saw kepada para sahabatnya sesaat setelah memenangkan peperangan Badar, suatu pertempuran dalam skala besar yang mempengaruhi dan mempertaruhkan eksistensi dan kontinuitas nasib ajaran Islâm di muka bumi ini. 
waktu dan tempat yang melingkupinya. ${ }^{8}$ Makna demikian merupakan istinbâth hukum syar'îi dari penggunaan istilah jihâd yang objek-nya tidak disebutkan secara eksplisit pada surat al-Hajj (22): 78 sebagaimana ditegaskan oleh M. Quraish Shihab, pakar tafsîr alQur'ân. ${ }^{9}$ Perang atas kekafiran maupun kemunafikan terhadap nafs (totalitas diri manusia) berimplikasi juga pada penafsiran bahwa jihâd diorientasikan pula untuk memerangi berbagai penyakit nafs dengan makna jiwa (psychological disease) yang ternyata dapat berdampak jauh lebih dahsyat daripada suatu pertempuran fisik karena terjadi terusmenerus sepanjang hayat. Bahkan berbagai peperangan diakui sering kali muncul dan terjadi dari penyakit-penyakit jiwa yang tak terkendali pada, utamanya, diri pemimpin-pemimpin institusi pemerintahan atau kenegaraan.

Bentuk-bentuk jihâd al-nafs yang seharusnya dikonsentrasikan untuk diperangi, antara lain berupa: (a) ambisi duniawi yang membengkak dan mengantar manusia untuk menguasai-penuh atau merampas kekayaan material sebanyak-banyaknya dari segala penjuru dengan segala cara, (b) prasangka buruk kepada Tuhan sehingga mengenyampingkan kesadaran tentang pengawasan Tuhan atas semua perilaku detail manusia, (c) terlena oleh glamour atau gemerlap duniawi yang menakjubkan sehingga menghabiskan waktu kehidupan, (d) perasaan lebih hebat daripada orang lain dalam status, jabatan, kemampuan ekonomik, derajat sosial, dan sejenisnya, (e) meremehkan perbuatan dosa kecil sehingga terbiasa menumpuk kesalahan-kesalahan, dan (f) riyấ, sum'ah, dan semacamnya. ${ }^{10}$

Dengan demikian, pemaknaan jihâd secara kontekstual harus lebih diorientasikan kepada "aksi peperangan" melawan hawa nafsu karena itu merupakan pintu masuk kemunculan aksi-aksi kekerasan fisik pada lingkup lokal, lebih-lebih global. Kendati pun begitu, memerangi orang-orang kâfir dan munâfik secara fisik dapat dimaklumi sejalan dengan konteks historis sebagaimana pernah dilakukan Rasûlullâh Saw. Tatkala itu, Rasûlullâh menerima ayat di Madinah yang memerintahkan untuk ber-jihâd (dalam pengertian

\footnotetext{
${ }^{8}$ M. Quraish Syihab, Wawasan Al-Qurân; Tafsir Maudhu'i atas Pelbagai Persoalan Umat (Bandung: Mizan, 1997), hlm. 506.

${ }^{9}$ Ibid.

${ }^{10}$ Ibid., hlm. 512.
} 
perang) karena nyata-nyata kaum kuffâr dan munâfiq melancarkan permusuhan dan penyerangan fisik yang tak tertahankan dan mengarah kepada peperangan terbuka. Karenanya, perintah ayat tersebut dapat dipahami bahwa aksi peperangan tidak boleh dilakukan untuk mendahului (pre-emptive action) sebagaimana yang biasa dilancarkan oleh/dan menjadi doktrin George Bush, George Walker Bush, dan Bush-Bush lainnya ketika hendak menyerang negara semisal Afganistan, Irak, Iran, dan Lebanon. Kondisi yang sama sangat mungkin terjadi di negeri ini akibat ulah sekelompok umat yang meniru tindakan menyerupai Bush.

Jelaslah bahwa ijin (perintah!) untuk berperang hanya dibolehkan untuk tujuan self-defence, yakni membela, melindungi, dan mempertahankan diri dari serangan pihak lain (kuffâr dan munâfiqîn). Dalam konteks ini dapat ditegaskan bahwa kendati pun terdapat sekelompok atau segolongan orang-orang kâfir maupun munâfik di lingkungan tempat tinggal umat Islâm dan/atau di negeri ini tetapi mereka tidak (bermaksud) menyerang atau memerangi umat Islâm maka tidak relevan jikalau umat Islâm memeranginya. Kendati pun begitu, dalam ajaran/doktrin Islâm tidak dikenal ketundukan atau kepasrahan kepada musuh sebagaimana kepasrahan total dalam ajaran/doktrin Bible, kitab suci umat Nashrani. ${ }^{11}$ Islâm justru mengajarkan atau mengijinkan agar umatnya melakukan pembalasan setimpal (qishâsh), atau bahkan memaafkannya jika secara mentalpsikologis mampu melakukannya, sebagaimana penegasan padadi dalam beberapa ayat al-Qur'ân berikut ini.

1. Surat al-Baqarah (2): 194.

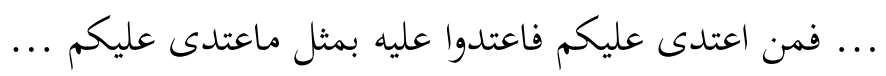

“...Siapa pun yang menyerangmu, maka seranglah dia secara setimpal dengan serangannya terhadapmu ...!)"12

2. Surat al-Nahl (16): 126.

$$
\text { وإن عاقبتم فعاقبوا بمثل ماعوقبتم به ولئن صبرتم لهو خير للصابرين }
$$

11 Dalam Bible terdapat doktrin agama: (“...jangan melawan orang jahat,melainkan barang siapa yang menampar pipi kananmu,berilah kepadanya pipi yang sebelah lagi". Matius:5/39)

12 Departemen Agama RI, Al-Qurân, hlm. 47 
"Jika kalian melakukan pembalasan, maka lakukanlah pembalasan itu secara setimpal sesuai dengan siksaan yang ditimpakan kepadamu; Tetapi jika kalian bersabar (mampu menahan diri untuk tidak membalas) maka itu lebih baik bagi orang-orang yang bersabar)" ${ }^{\prime 13}$

3. Surat al-Baqarah (2): 190.

$$
\text { وقاتلوا فى سبيل الله الذين يقاتلونكم ولا تعتدوا إن الله يحب المحسنين }
$$

"Perangilah di jalan Allah orang-orang yang memerangi kalian (tetapi) janganlah kalian melampaui batas. Allah tidak menukai orangorang yang melampaui batas). ${ }^{14}$

4. Surat al-Baqarah (2): 191.

$$
\text { .... فإن قاتلوكم فاقتلوهم كذلك جزاء الكافرين }
$$

"Jika mereka memerangi kalian, maka peranghilah mereka, begitulah balasan orang-orang yang kâfir). ${ }^{15}$

5. Surat Al-Tawbah (9): 36.

$$
\text { .... ... وقاتلوالمشركين كافة كما يقاتلونكم كافة }
$$

"Perangilah orang-orang musyrik secara menyeluruh sebagaimana mereka memerangi kalian secara menyeluruh). ${ }^{16}$

\section{Identitas Kâfir}

Suatu aksi kekerasan dalam berbagai jenis dan bentuknya tidak dapat dibenarkan secara hukum dalam ajaran Islâm kecuali didahului oleh aksi tindak kekerasan pihak lain yang seakidah, lebih-lebih oleh orang lain yang tidak seiman-seakidah (kâfir dan/atau munâfik). Pernyataan ini merupakan doktrin keberIslâman, sebagaimana ditegaskan oleh Allâh swt. dalam al-Qur'ân surat al-Hujurât (49): 9 berikut ini.

\footnotetext{
13 Ibid., hlm. 421.

14 Ibid., hlm. 46.

15 Ibid., hlm 46.

16 Ibid., hlm. 284.
} 


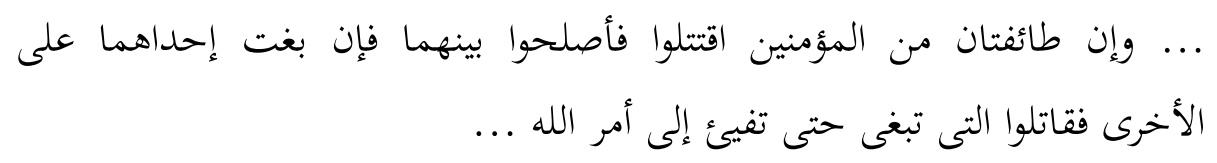

“... Jika ada dua kelompok di antara orang-orang beriman saling berperang maka damaikanlah keduanya! Jika salah satu dari kedua kelompok itu (sesudah didamaikan) masih bertindak curang dengan menyerang kembali kelompok lainnya maka perangilah kelompok yang curang itu sampai kelompok itu kembali kepada perintah Allah.... ${ }^{17}$

Kekufuran yang "dianut" oleh diri individu atau kelompok tertentu tidaklah begitu saja dapat menjadi alasan-pembenar bagi umat Islâm untuk menyerang atau memerangi mereka. Hal itu sangat terkait dengan identitas dan intensitas kekafiran mereka. Pada konteks itulah, para pakar hukum Islâm (fuqahâ') menggolongkan orang kâfir dalam dua jenis. Pertama, golongan kâfir harb̂̂̀ yaitu kelompok orang-orang (kâfir) yang memerangi umat Islâm. Kepada kelompok ini umat Islâm diijinkan Allâh untuk memeranginya. Kedua, golongan kâfir ghayr harbî yaitu kelompok orang-orang (kâfir) yang tidak (berniat hendak) memerangi umat Islâm. Karenanya, umat Islâm tidak boleh memeranginya.

Di samping itu, kâfir ghayr harbiy digolongkan lagi dalam dua kelompok. Pertama, kelompok kâfir mustakmin yaitu golongan orangorang non Muslim yang mengikat perjanjian dan perlindungan jaminan keamanan dari umat atau negara Islâm.Terhadap mereka itu harus dilindungi keamanannya karena posisi inferioritasnya oleh umat Islâm, sebagaimana perintah al-Qur'ân pada surat al-Tawbah (9): 6 berikut ini.

$$
\text { وإن أحد من المشركين استجارك فأجره حتى يسمع كلام الله ثم ابلغه مأمنه }
$$

"Jika seorang musyrik (yang memusuhimu) meminta Perlindungan kepadamu, lindungilah dia!, barangkali ia sudi mendengar firman Allâh dan antarkanlah dia ke tempat yang aman!). 18

Sebutan teknis bagi kâfir mustakmin adalah kâfir dzimmî. Perlindungan bagi mereka itu dilakukan atas keselamatan fisiknya

${ }^{17}$ Ibid., hlm. 846.

${ }_{18}$ Ibid., hlm. 278. 
maupun keamanan keyakinan akidahnya. Bahkan Nabî saw pernah bersabda, "siapa pun yang menyakiti kâfir dzimmî sesungguhnya menyakitiku; maka akulah yang akan menuntut-balas untuknya di akhirat" (al-Hadîts).

Kedua, kelompok kâfir mu'âhid yaitu golongan orang-orang non Muslim yang mengikat janji dengan umat Islâm untuk menjalin pergaulan hidup-bersama dan berdampingan secara damai. Posisi mereka relatif setara dengan posisi umat Islâm dalam level ekonomik, sosial, politik, maupun kultural. Dalam konteks itu perlu disimak kembali ayat al-Qur'ân pada surat al-Mumtahanah (60): 8 beriku ini:

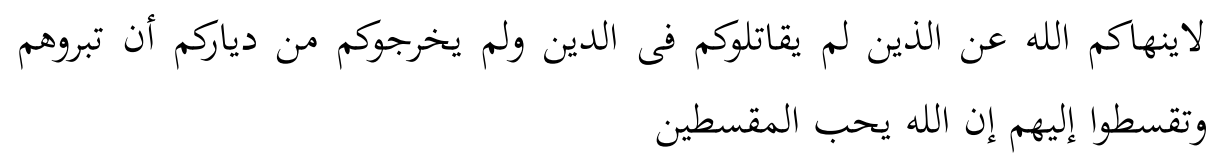

"Allah tidak melarang kalian (umat Islam) untuk berlaku adil kepada umat lain yang tidak memerangi dan tidak mengusir kalian karena alasan agama. Sungguh Allah menyukai orang-orang yang bertindak adil". ${ }^{19}$

Dalam posisi kesetaraan itu, "hukum tertinggi" yang mengikat kedua pihak itu adalah aturan main jalinan pergaulan hidup berupan kesepakatan-kesepakatan sosial. Kondisi demikian pernah dialami oleh Rasûlullâh saw dan para sahabat-sahabatnya di negeri Madînah. Kondisi itu tampaknya relatif serupa dengan situasi umat Islâm dewasa ini di negeri ini.

\section{Jihâd: Menegakkan Kebenaran}

Oleh karena istilah jihâd tidak dengan sendirinya identik dan/atau dapat diidentikkan dengan perang-fisik melawan orangorang kâfir (termasuk di dalamnya orang-orang munâfik yang jelasjelas berbeda dalam akidah keagamaan), maka harus ditemukan makna lain yang relatif lebih sesuai dengan konteks penggunaannya. Jika dicermati lebih mendalam, di dalam al-Qur'ân ditemukan sekitar 49 ayat tentang anjuran (perintah!) ber-jihâd bagi umat Islâm. Tiga ayat di antaranya dapat dimaknakan sebagai pertempuran fisik untuk menghadapi orang-orang kâfir dan/atau munâfik, walaupun dengan catatan yang amat tegas yakni jika mereka melancarkan aksi

19 Ibid., hHlm. 924. 
penyerangan lebih dahulu. Selebihnya, 46 ayat al-Qur'ân merangkaikan penggunaan istilah jihâd dengan frasa fî sabîlillâh, yang diartikan sebagai perjuangan (bukan pertempuran atau peperangan fisik) di jalan Allâh. Pemaknaan demikian tampaknya lebih sesuai dengan konteks penggunaannya karena ayat tersebut secara eksplisit tidak menyebut atau menyertakan objek yang menjadi sasarannya.

Oleh karenanya, istilah jihâd haruslah dimaknakan sebagai perjuangan di jalan Allah untuk tujuan penegakan kebenaran dan nilai-nilai keluhuran universal kemanusiaan, yaitu untuk mewujudkan kepentingan semua pihak, siapa pun mereka dalam golongan agama, ideologi, ras, etnik dan sejenisnya. Apalagi, jika dipertalikan dengan keimanan umat Islâm bahwa Allâh, dengan sifat rahman-Nya, senantiasa merahmati seluruh makhluknya tanpa membedakan agama, keyakinan, ideologi, bahasa, warna kulit, ras, dan suku bangsanya. Sasaran utama jihâd fî sabîlillâh, dengan demikian, tidak selalu ditujukan kepada orang atau sekelompok orang secara fisik melainkan kepada sistem atau tata kehidupan yang secara hakiki melawan nilai-nilai universal kemanusiaan, yakni keadilan dalam kerangka fî sabîlillâh. Dalam bahasa inklusifnya, sasaran jihâd yang utama, mendasar, dan universal adalah perilaku kedzaliman sebagai lawan utama dari keadilan.

Rekontekstualisasi pemaknaan jihâd demikian (sebagai perjuangan untuk kebenaran dan keadilan dalam framewok ajaran Allâh dan tidak selalu diartikan sebagai peperangan) dimaksudkan untuk mengingatkan kembali bahwa ada beberapa hal yang harus diperhatikan terkait dengan ayat-ayat yang menjelaskan tentang perang. Pertama, jumlah ayat-ayat perang di dalam al-Qur'ân benarbenar sangat terbatas bila dibandingkan dengan ayat-ayat damai, yang berarti bahwa ajaran tentang kedamaian lebih diutamakan daripada tindakan peperangan. Kedua, persyaratan untuk melakukan perang dalam Islâm sangatlah rigid, antara lain tidak dibenarkan melampaui batas (misalnya, menyakiti kaum perempuan, anak-anak, dan orang-orang tua, serta tidak merusak kemaslahatan umum seperti tempat ibadah, sarana, dan prasarana publik/sosial) kendati pun mereka nyata-nyata berbeda dalam akidah dan prinsip hidup maupun berlainan golongan, ras, dan etnik. Ketiga, perang hanya diijinkan oleh Islâm pada situasi dan kondisi amat memaksa untuk membela diri ketika jelas-jelas musuh akan atau sedang menyerang. 


\section{Taufiqurrahman}

Keempat, perang hanya boleh dilakukan untuk membela terjadinya ancaman-serius atas kebebasan asasi (fitrah) kemanusiaan dan keimanan atas keyakinan ajaran agama.

Kondisi demikian pernah dialami Rasûlullâh saw tatkala beliau tidak diberi "ruang bernafas" oleh orang-orang Quraisy yang mengancam keselamatan ajaran Islâm dan perlindungan umat dengan berbagai teror, aksi kekerasan mental maupun fisik, dan niat untuk melangsungkan peperangan. Dalam konteks itulah dapat ditarik implikasi fenomenologis atas fakta dan peristiwa kekerasan yang terjadi dan marak belakangan ini di negeri ini karena dinilai telah melenceng-jauh dari ajaran dan spirit Islâm. Mereka mengecam kebebasan asasi bukan membelanya; memberangus keyakinan bukan melindunginya, bahkan menutup dan merusak tempat-tempat ibadah. Padahal aksi-aksi semacam itu sesungguhnya menjadi "garis demarkasi" atau "batas-garis merah" yang harus dipatuhi karena telah menjadi konvensi untuk tidak dilanggar dalam aturan main peperangan, lebih-lebih menurut ajaran Islâm. Begitu juga dengan fenomena dan peristiwa bom bunuh diri, tidak dibenarkan untuk disebut sebagai jihâd karena perilaku bunuh diri (dalam segala jenis dan bentuknya) berarti putus asa untuk terus memperjuangkan sebuah keyakinan yang jelas-jelas terlarang dalam ajaran Islâm.

Menarik disimak dan dipahami secara mendalam tatkala Rasûlullâh Saw dengan bijaksana pernah bersabda bahwa kalian umat Islâm akan (terus-menerus dan senantiasa) menghadapi perang yang lebih besar dari perang Badar, yaitu "perang" atau perjuangan melawan nafsu. Perjuangan seperti itu dimaknakan sebagai suatu upaya secara sungguh-sungguh untuk menahan diri dan tidak menganggap diri memiliki pemahaman yang paling sempurna sementara yang pihak lain dianggap paling tidak sempurna. Dalam konteks pemahaman seperti itu, pemaknaan jihâd dalam mental kognitif umat Islâm sangat menentukan sehingga tidak akan gegabah untuk mengartikan jihâd semata-mata "berwajah tunggal" dengan satu penafsiran: peperangan fisik. Jika kemudian terjadi sebaliknya maka tidak mustahil akan terjadi tindakan pemberangusan keyakinan-keagamaan yang dinilai berbeda terhadap kelompok internal, lebih-lebih eksternal keagamaan, pembunuhan terhadap orang-orang yang semestinya secara syar' $\hat{\imath}$ wajib dilindungi), perburuan terhadap orang-orang yang berlainan kepentingan 
pragmatis-ideologis, dan penutupan tempat-tempat ibadah karena semua itu dianggap "menyalahi kehendak" Tuhan menurut penilaian eksklusif dan sepihak dari sekelompok golongan tertentu.

\section{Rekontekstualisasi Jihâd: Suatu Agenda}

Seorang pemikir dan pembaru Mesir, Gamal al-Banna, menyatakan bahwa jihâd merupakan prinsip dasar dalam ajaran Islâm sebagai prinsip hidup secara umum. ${ }^{20}$ Jihâd sesungguhnya berarti upaya yang dilakukan secara sungguh-sungguh dengan mengerahkan kekuatan penuh (badzl al-juhd, all-out) untuk menghadirkan kebenaran sehingga dapat dicapai tatanan yang berkeadilan. Semangat jihâd demikian tidak dibatasi hanya dalam level kehidupan tertentu tetapi dalam kehidupan umat manusia secara umum. Oleh karenanya, jihâd bukan hanya diposisikan sebagai perspektif, strategi, maupun pendekatan tetapi juga sebagai manhaj (metodologi), orientasi, pola, dan prinsip-prinsip dalam berkehidupan. ${ }^{21}$ Jelaslah sudah bahwa kontekstualisasi pemaknaan jihâd diorientasikan pada manhaj dalam mengerahkan kekuatan secara penuh dan sungguh-sungguh untuk tetap berada pada jalur kebaikan, membangun kemaslahatan bersama, meninggalkan kemudlaratan, dan tidak tergoda oleh "rayuan mental" untuk melakukan aksi-aksi kekerasan maupun penyerangan fisik yang "berlindung di balik" klaim kebenaran tafsîr-makna atas teks al-Qur'ân. Apalagi, secara umum al-Qur'ân menggunakan istilah jihâd untuk dirujukkan kesesuaiannya dengan totalitas esensi keberadaan al-Qur'ân itu sendiri sebagai acuan utama umat dalam berpikir, bersikap, dan berperilaku. Dalam al-Qur'ân surat al-Furqân (25): 52 ditegaskan bahwa:

$$
\text { فلا تطع الكافرين وجاهدهم به جهادا كبيرا }
$$

"Janganlah kalian mengikuti orang-orang kâfir, dan berjihâdlah terhadap mereka dengan al-Qur'ân dengan (cara) jihâd yang agung).22

Sebagai bagian dari prinsip dasar ajaran Islâm, jihâd haruslah memiliki beberapa "agenda harian" yang perlu dilaksanakan secara

\footnotetext{
${ }^{20}$ Gamal al-Banna, Al-Jihâd (Mesir: Musthafâ al-Bâbî al-Halaby, 2002), hlm. 12.

21 Ibid., Hlm. 17.

22 Departemen Agama RI., Al-Qurân, hlm. 567.
} 


\section{Taufiqurrahman}

konsisten, sebagaimana tawaran Gamal al-Banna. Pertama, berpegang teguh kepada hidâyah dan nilai-nilai luhur al-Qur'ân, ${ }^{23}$ dalam arti agar umat Islâm senantiasa menggunakan al-Qur'ân dalam pemahaman dan aktualisasi ber-jihâd. Hal itu didasari argumen bahwa (a) Islâm masuk ke Madînah bukan dengan pedang (aksi kekerasan) melainkan dengan al-Qur'ân yang dibacakan oleh Mus'ab bin 'Umayr; (b) Abû Jahal yang begitu keras memusuhi Nabî Muhammad menjadi luluh dan tidak jadi melaksanakan salah satu rencana jahatnya karena sempat mendengarkan bacaan al-Qur'ân; dan (3) 'Umar yang bertemperamen sangat keras dan ganas menjadi bersimpuh karena lantunan ayat-ayat al-Qur'ân. Karenanya, perlu dipahami bahwa berpegang teguh kepada al-Qur'ân tidak cukup hanya dengan membaca dan menghafalkan ayat-ayatnya secara tekstual melainkan berupaya membuka pintu utama menuju "lautan nilai-nilai luhur" di dalamnya melalui intensitas pemahaman dan perenungan secara sungguh-sungguh.

Kedua, bersabar dan tetap tekun dalam berjuang. Perjuangan merupakan rangkaian upaya sungguh-sungguh yang sangat panjang dan boleh jadi melebihi usia pejuangnya. Rintangan yang bermacammacam, dalam jenis dan bentuknya, pasti melintang dan menghadang yang tidak boleh melemahkan dan melelahkan semangat juang sang mujahid. Ketiga, bersikap bijaksana, yang dalam bahasa al-Qur'ân disebut hikmah (arif dan bijak), maw'idhah hasanah (dialog konstruktif) dan mujâdalah bi al-latî hiya ahsân (berkomunikasi untuk menemukan jalan terbaik). Keempat, pengorbanan dalam bentuk harta atau bahkan jiwa perlu menjadi bagian tak terpisahkan di dalamnya. Tidak ada perjuangan tanpa pengorbanan. Bahkan didalam al-Qur'ân terdapat ayat-ayat yang menganjurkan betapa penting suatu pengorbanan. ${ }^{24}$

Pengorbanan dalam bentuk harta memang sangat bisa dimaklumi tetapi bagaimana dalam bentuk jiwa? Bukankah itu termasuk bagian dari perbuatan bunuh diri? Pengorbanan jiwa dalam perjuangan itu tidak boleh dimaknai negatif, yakni penyerahan diri dengan sengaja kepada kematian, apalagi bunuh diri. Secara esensial, pengorbanan jiwa membutuhkan prasyarat tertentu, yaitu: (a)

\footnotetext{
${ }^{23}$ Al-Qur'ân, surat al-Furqân (25): 52.

${ }^{24}$ Ibid., surat al-Nisấ(4): 95; idem, al-Anfâl (8): 72; al-Tawbah (9): 88; dan al-Hujurât (49): 15.
} 
ketidaksengajaan. Seseorang yang berjuang (dalam perang sekali pun) tidak boleh berhasrat menyerahkan dirinya pada pihak lawan untuk dibunuh. Bila itu terjadi berarti yang bersangkutan tak lagi menjunjung tinggi nilai-nilai luhur yang diperjuangkan. Mati dalam keadaan demikian bukanlah meninggal dalam perjuangan tetapi bunuh diri walaupun tidak secara langsung; (b) pembelaan diri, yakni pengorbanan jiwa bisa memiliki makna dan nilai yang tinggi jika itu terjadi karena mempertahankan dan melindungi diri dari serangan lawan.

Kelima, menganjurkan pada kebaikan dan bertahan sejauh mungkin dari keburukan (al-amr bi al-ma'rûf wa nahy 'an al-munkar). Fenomena yang terjadi selama ini adalah suatu aksi dari sekolompok orang yang tidak hanya menganjurkan atau memerintahkan tetapi menyuruh-paksa orang lain untuk berbuat baik dan tidak hanya melarang tetapi melibas perbedaan dengan cara memporakporandakan dan menghancurkan sarana yang digunakan dan ditempatinya. Akibatnya, terjadi aksi pemaksaan (untuk berbuat baik) dan terjadi pemusnahan sarana fisik semata-mata karena terdapat suatu ketidakseragaman pandangan dan pemahaman. Inilah bagian dari gambaran tentang distorsi pemahaman terhadap ajaran Islâm. Akibatnya terjadi eksklusivitas dalam bentuk pengukuhan sikap yang menganggap paling benar sendiri, paling selamat sendiri, dan paling baik sendiri yang memperoleh tempat dan penguatan dalam tatanan masyarakat. Keberagamaan yang eksklusif itu muncul karena distorsi atas pemaknaan al-amr bi al-ma'rûf wa nahy 'an al-munkar dengan wajah tunggal dan sepihak. Padahal, pemaknaan ini tidak sejalan dengan ayat lain di dalam al-Qur'ân semisal ayat 3 surat al-'Ashr (103), yaitu:

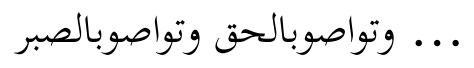

"...Saling berwasiatlah dalam kebenaran dan kesabaran". 25

Anjuran Islâm hanyalah sebatas menasihati, bukan memaksa, karena yang paling tahu tentang hakikat kebaikan dan keburukan hanyalah Allâh, Dzat Yang Maha Sempurna, sedangkan manusia

${ }^{25}$ Departemen Agama RI., Al-Qur'an, hlm., 1099. 


\section{Taufiqurrahman}

(termasuk dalam memahami kebaikan dan keburukan) penuh keterbatasan dalam menjustifikasi suatu kebenaran.

Keenam, mengakhiri perbuatan buruk dengan perbuatan baik. Kecuali Nabî, tidak ada seorang manusia pun yang disucikan dari perbuatan buruk sebagai konsekuensi dari kekurangan dan keterbatasan yang dimilikinya. Oleh karenanya, seseorang menjadi buruk bukan karena perbuatan buruknya, tapi karena tak mau mengakhiri (dengan kebaikan) perbuatan buruknya itu. Dalam ajaran Islâm disebutkan bahwa setiap keturunan Âdam itu memiliki kecenderungan untuk berbuat salah, di samping juga berbuat benar. Sebaik-baik orang yang berbuat salah adalah mereka yang segera bertaubat.

Ketujuh, berhijrah dalam arti mental, fisik, ataupun pendekatan. Ketika dalam suatu kondisi tertentu ditemukan jalan buntu, maka jalan berikutnya adalah hijrah. Yang penting diperhatikan dari hijrah adalah semangat progresivitas dan kontinuitas. Seseorang yang hijrah bukan berarti hendak meninggalkan nilai-nilah luhur yang sedang diperjuangkan melainkan pindah dari satu pendekatan ke pendekatan lain hingga tercapai target yang diperjuangkan. Begitulah Nabî Muhammad memberi keteladanan dalam melakukan hijrah. Pertanyaannya kemudian, dari mana awal pemaknaan jihâd dengan kekerasan sebagaimana marak belakangan ini? Jawabannya adalah ketika jihâd dipahami dari sebagai perang atau qitâl.

\section{Penutup}

Istilah jihâd dipandang sangat istimewa bukan karena mampu "menggetarkan" telinga pendengarnya tetapi karena merupakan aktualisasi dari praksis keberagamaan individu Muslim yang diposisikan sebagai parameter dan evidensi keberagamaan. Oleh karenanya, jihâd menempati derajat yang tinggi sebagai alat ukur pada kehidupan nyata atas keberimanan seseorang dalam bentuk keteguhan persepsi, pikiran, pendapat, pandangan, sikap, dan penghayatan untuk menegakkan (baca: diperjuangkan!) kebenaran dalam pergaulan hidup sehari-hari.

Pemahaman atas konstruk jihâd yang mendasarkan diri pada firman Allâh, tampaknya harus dimaknakan kembali menurut konteks kepatuhan hamba kepada Sang Pencipta untuk meneguhkan sikap mental-kognitif yang hanya berpihak kepada ajaran-Nya sebagai 
cara untuk menghadirkan kebenaran. Oleh karena itu, jihâd harus diposisikan sebagai bagian dari bentuk-bentuk perjuangan yang penuh dengan spirit pengorbanan untuk memunculkan dan membela kebenaran dalam berbagai aspek dan realitas kehidupan. Itulah yang dikenal dengan makna rekontekstualisasi pemaknaan jihâd sebagai reformulasi tawaran makna-baru. Dalam istilah lain, jihâd dimaknakan sebagai menghadirkan dan membela kebenaran. Sehingga terwujud keadilan dan keberaturan dalam tatanan sosioyuridis yang merata dan berlaku bagi semua orang tanpa kecuali.

Pemaknaan jihâd secara kontekstual harus lebih diorientasikan kepada aksi perlawanan kepada hawa nafsu karena itu merupakan pintu masuk kemunculan aksi-aksi kekerasan fisik pada lingkup lokal maupun global, sebagai upaya yang mesti dilakukan secara sungguhsungguh dengan mengerahkan kekuatan penuh (badzl al-juhd, all-out) untuk menghadirkan tatanan yang berkeadilan. Semangat jihâd demikian tidak dibatasi hanya dalam level kehidupan tertentu tetapi dalam kehidupan umat manusia secara umum. Oleh karenanya, jihâd bukan hanya diposisikan sebagai perspektif, strategi, maupun pendekatan tetapi juga sebagai manhaj (metodologi), orientasi, pola, dan prinsip-prinsip dalam berkehidupan.

Kontekstualisasi pemaknaan jihâd perlu diorientasikan pada manhaj dalam mengerahkan kekuatan secara penuh dan sungguhsungguh untuk tetap berada pada jalur kebaikan, membangun kemaslahatan bersama, meninggalkan kemudlaratan, dan tidak tergoda untuk melakukan aksi-aksi kekerasan maupun penyerangan fisik yang "berlindung di balik" kebenaran makna teks al-Qur'ân. Apalagi, secara umum al-Qur'ân menggunakan istilah jihâd untuk dirujukkan kesesuaiannya dengan totalitas esensi keberadaan alQur'ân itu sendiri sebagai acuan utama umat dalam berpikir, bersikap, dan berperilaku. Wallâh a'lam bi al-shawâb.

\section{Daftar Pustaka}

Banna, Gamal al-. Al-Jihâd. Mesir: Musthafâ al-Bâbî al- 


\section{Taufiqurrahman}

Bisri, Adib \& Munawwir AF. Al-Bisri: Kamus Arab-Indonesia dan Indonesia-Arab, Surabaya: Pustaka Progresif, 1999.

Departemen Agama RI. Al-Qu'rân dan Terjemahnya. Jakarta: Proyek Pengadaan Kitab Suci Al-Qur'ân, 1999.

Munawwir, Ahmad Warson. Al-Munawwir: Kamus Arab-Indonesia. Yogyakarta: Pondok Pesantren Al-Munawwir Krapyak, 1984.

Syihab, M. Quraish. Wawasan Al-Qurân; Tafsir Maudhu'i atas Pelbagai Persoalan Umat. Bandung: Mizan, 1997. 